Acta Poloniae Historica

109,2014

PL ISSN 0001-6892

Włodzimierz Mędrzecki

\title{
THE SOCIETY OF THE SECOND REPUBLIC OF POLAND REVISITED: THE NATIONALITY ISSUES
}

\begin{abstract}
This article presents the main goals and the programme of 'The Society of the Second Republic of Poland: An attempt at a new synthetic approach', a research project pursued in the Institute of History, Polish Academy of Sciences, Warsaw. A conference discussing the ways in which national and ethnic factors informed the interwar Polish society, held most recently (in 2012) as part of the project, is discussed in some detail. The article introduces the papers first delivered at the conference and now published in the present issue of Acta Poloniae Historica.
\end{abstract}

Keywords: Second Republic (of Poland), ethnic relations, national identity, localness.

Janusz Żarnowski's book Społeczeństwo II Rzeczypospolitej, published in $1973,{ }^{1}$ has been one of the major Polish historiographic achievements with respect to the interwar period of 1918-39. Whilst the point of departure for the author was the Marxist model of capitalist class society, it has been modified considerably. As a result, Żarnowski has proposed to describe the population of interwar Poland in terms of a combined 'class-and-stratum' pattern, featuring the working class, peasantry, intelligentsia and white-collar workers, bourgeoisie, petty bourgeoisie, landowners, and 'the derailed and marginal elements'.

The basic stratification of the society into classes and strata has been nuanced by this author by indicating other than class-related factors influencing the model of life and positions of the individual social milieus as well as constructing social hierarchies, including

${ }^{1}$ Janusz Żarnowski, Społeczeństwo Drugiej Rzeczypospolitej, 1918-1939 (Warsaw, 1973).

2 Ibidem, 32. 
ethnic and national or territorial ones (urban/rural areas, regional and inter-Partition differences), or those related to cultural diversity. As a result, an elegant and clear model of the social structure of interwar Poland has emerged, richly documented, moreover, with manifold source material. It was unreservedly accepted by specialists and by a wider circle of the reading public interested in historical knowledge. To date, an overwhelming share of books dealing with the interwar period quote or mention the J. Żarnowski's book as a reference; similarly, a definite majority of school textbooks describe the 'class-and-stratum' structure merely as the social structure of the Second Republic.

2010 saw the kickoff of the research scheme titled 'The Society of the Second Republic of Poland: An attempt at a new synthetic approach' at the Nineteenth- and Twentieth Century Social Transformations Research Laboratory, Institute of History, Polish Academy of Sciences. The objective is to confront the findings of the 1970s with our contemporary social sciences' and humanities' reflection based on research into the social structure, and the current state of research in the social history of interwar Poland. ${ }^{3}$ The project is essentially to define, and make at least an attempt at initial analysis, of the major drivers which, along with the 'class-and-stratum' divisions, informed the model of social life and determined the way and standard of life of inhabitants of interwar Poland.

Resulting from the discussion, attended by the invited exponents of most of the scholarly milieus pursuing studies on the Second Republic, it has been decided that a series of conferences be held, dealing with subject-matters such as:

- The role of the State as a factor co-shaping the social life of Poland; 4

- Labour as a factor co-shaping the society's structure; ${ }^{5}$

- The role of religion in the shaping of a social life model; ${ }^{6}$

${ }^{3}$ The project, managed by Janusz Żarnowski, has been enabled by the funding granted by the Ministry of Science and Higher Education.

${ }^{4}$ Janusz Żarnowski (ed.), Państwo i spoteczeństwo Drugiej Rzeczypospolitej (Metamorfozy społeczne, 8, Warsaw, 2013).

${ }^{5}$ Cecylia Leszczyńska and Włodzimierz Mędrzecki (eds.), Praca i społeczeństwo Drugiej Rzeczypospolitej (Metamorfozy społeczne, 9, Warsaw, 2014).

${ }^{6}$ Tadeusz Stegner (ed.), Religia a spoteczeństwo Drugiej Rzeczypospolitej (Metamorfozy społeczne, 5, Warsaw, 2013). 
- Culture ${ }^{7}$ and socialisation processes (conditional upon the social and national milieu); 8

- The demographic determinants of the Second Republic society; ${ }^{9}$

- Analysis of the social outcast milieus and marginalisation processes; $i^{10}$ and,

- The influence of national/ethnic drivers on the shape of interwar Poland's society.

The last of the aforementioned conferences, organised by Olga Linkiewicz and Kamil Kijek, was held in January 2012, with the intention to, primarily, tackle two exercises. First, give an answer to the question of what is, presently, the most interesting thing or object for the milieu of researchers studying the issues of the ethnic and national relations in the interwar period. Second, consider the purposefulness of commencing a new stage of discussion on the role of nationality questions in the shaping of a comprehensive model of Poland's social life in the interwar period. Based on analysis of multiple sources and on historical literature dealing with ethnic and national relations in the Second Republic, the conclusion can be drawn that the incessant conflict involving and affecting the nations populating the territory of Poland was, outright, essential to the country's history. Every actor fought for their inalienable and natural rights whose apple-of-the-eye was a sovereign national state. Conflicts would be inevitable, their intensity so remarkable that it posed a real threat to the country's and state's stability and entirety.

That many Second Republic citizens, particularly those belonging to the enlightened strata, perceived the relations inter nations as the central aspect of social reality seems pretty comprehensible. They were educated and then active in an epoch that considered nations

${ }^{7}$ Włodzimierz Mędrzecki and Agata Zawiszewska (eds.), Kultura $i$ spoteczeństwo II Rzeczypospolitej (Metamorfozy społeczne, 4, Warsaw, 2011).

${ }^{8}$ Anna Landau-Czajka and Katarzyna Sierakowska (eds.), Procesy socjalizacji w Drugiej Rzeczypospolitej 1914-1939 (Metamorfozy społeczne, 7, Warsaw, 2013).

${ }^{9}$ Two papers delivered at the Symposium have been published; see Szymon Słomczyński, “There Are Sick People Everywhere - in Cities, Towns and Villages": The Course of the Spanish Flu Epidemic in Poland', Roczniki Dziejów Spotecznych $i$ Gospodarczych, lxxii (2012), 73-93; and, Bartosz Ogórek, 'Płodność populacji II Rzeczypospolitej przy użyciu indeksów Pincerton European Fertility Project', ibidem, 95-124.

${ }^{10}$ Mateusz Rodak (ed.), Margines spoteczny Drugiej Rzeczypospolitej (Metamorfozy społeczne, 6, Warsaw, 2013). 
as the most important human community. In the late nineteenth and in the first half of the twentieth century, nations were commonly perceived as collective beings, equipped with self-awareness, and consistently pursuing the basic objective forming part of their very essence - that is, building of a nation-state. The nation thus defined was ascribed a capacity of forming its members so that they were prepared, whether consciously or instinctively, for contributing to the collective actions taken in view of pursuing the national goals, particularly if the national interests were put under threat. Nation was thus furnished with multiple traits and attributes, such as possessing a collective wisdom and will, instinct, spirit or, finally, character. It was assumed that there existed some natural form of political selfactualisation and existence of nation, this being a nation-state; the rule of self-determination of nations, as formulated in the course of the Great War, was deemed compliant with the objectively existing general regularity of development of human communities or societies. As a direct consequence of such perception of the essence of nation was the acknowledgment that a nation's struggle for a sovereign existence is not only the nation's right but, outright, its historical obligation.

It was considered that the strength of a nation, especially if deprived of its state, is founded on two pillars: its numerical force and its solidarity and ability to sacrifice individuals to the benefit of a community. Hence, each nation ought to develop its national culture as a complex of symbols integrating and mobilising all of its members, and to create mechanisms of socialisation of its young generations so that they be educated into the spirit of patriotism, readiness to struggle, and sacrifice for the community.

An important element of the complex of ideas being described was the conviction whereby every individual belongs to a concrete national community, even when he or she is not aware of this fact or shuns an unambiguous national self-identification. This principle, applied in practice, led to a development of national missionary, that is, actions aiming at nationalising all those who were not yet aware of their affiliation with the community. Given the social and cultural realities of what had been the Commonwealth of the Two Nations, this must have led to a reappearing 'rivalry for the souls' of those who, for whatever reason, had not unambiguously declared their belonging.

In the light of various sources, it may be guessed that they belonged to diverse groups and milieus whose perhaps only common feature 
was inability to fit in the framework set by the modern nationalisms. Such people would most frequently define themselves as 'local', which emphasised that the factor determining their self-identification was a sense of affiliation with a specific place or region. Three geographies are identifiable where the phenomenon of 'localness' appeared with peculiar frequency in the interwar period. One of them was a small area of land located in the east, between the Wilno Land (where Polish national self-identification was dominant) and Volhynia (whose inhabitants unambiguously described themselves as Ukrainians). Asked 'Who are you?', a definite majority of rural dwellers of the area defined themselves as 'local', or a muzhyk (peasant). In the regions of Grodno and Nowogródek, a considerable group of the 'locals' were Catholics; the areas of Polesia and Volhynian Polesia were almost entirely Orthodox. The other area where 'localness' was quite intense was considerable extents of Galicia - from the vicinity of Gorlice in the west up to the eastern counties of Tarnopol Voivodeship. In Galicia, 'localness' was not as frequent as in Polesia, but it was present there to the extent enabling it to influence the social life model and the culture of these provincial areas. It is worth mentioning on this occasion that both regions were moreover home to yet another milieu that was significant in terms of size, and which identified itself not through an ethnic but estate declaration (as 'nobility' - szlachta). ${ }^{11}$ These were descendants of petty nobility densely populating not only the localities but the whole areas; remaining different against their surrounding muzhyk ocean was a central priority for them. Upper Silesia was another territory in which a significant part of dwellers described themselves as 'local'.

The juxtaposition of areas as different in terms of ethnic, religious, and social structure, and degree of development, as Polesia, Galicia and Silesia, shows in itself how complex was the tangle of phenomena that the declaration of 'localness' represented. Such 'localness' often expressed a fear of making a clearer declaration which could have destroyed the existing arrangement of local relations. In many cases, 'localness' stood for inability or reluctance to choose

${ }^{11}$ Cf. Magdalena Kwiecińska, 'Świadomość historyczna potomków drobnej szlachty okolic Sambora wobec kształtującej się ukraińskiej tożsamości narodowej po rozpadzie Związku Radzieckiego', Ph.D. thesis, Jagiellonian University, Cracow, 2009; <http://jbc.bj.uj.edu.pl/publication/185213> [Accessed Nov. 28, 2013]. 
the self-identification factors one deems the most important - such as language, religion, descent, family ties, etc.; and, it often reflected the current arrangement of the circumstances. It has to be emphasised that for the Belarusian and Ukrainian national movement, 'localness' posed a substantial problem not only due to the policy pursued by the Polish authorities. From a historical perspective, it is apparent that the hopes, which were expressed at times, for Polonisation of a definite majority of dwellers of Grodno and Nowogródek regions, and of Polesia, merely reflected a wishful thinking (as Józef Obrębski demonstrated, before 1939)..$^{12}$ Given the complexity of the relations in Galicia, no less important for the nationalists was the distinction between, and separation of, the Belarusians and the Ukrainians, as was the unambiguous ascription to the ethnic communities of representatives of communities such as Ruthenian (which was not necessarily Ukrainian) nobility, Old-Ruthenians, the Lemko, Boyko or Hutsul people.

A no less complex tangle of issues was connected with identity processes among Jews and in the environments on the Polish-Jewish borderland. It suffices to notice that the interwar period witnessed a fast-progressing process of quitting Yiddish in various Jewish milieus. Some of them would switch into Hebrew, whilst others (how many of them, is hard to define without precise research) used Polish only. This leads one to a question about the ways in which linguistic processes influenced the self-identification of at least some of the people of Mosaic religion. ${ }^{13}$

The above remarks enable one to understand why a considerable portion of sources produced in the interwar period by governmental and social institutions as well as by national, political, social, etc. activists contains the message stating that national/ethnic communities was the category that organised the social life. We would find no explanation there, though, why such 'nation-centric' perspective on the reality of interwar Poland has been shared until today by so many historiographers. Symptomatic in this respect has been the search for 'objective' indications using which 'estimation of the national/

${ }^{12}$ Piotr Cichoracki analyses this particular issue at length in this Acta Poloniae Historica fascicle.

${ }^{13}$ Anna Landau-Czajka, Syn będzie Lech... Asymilacja Żydów w Polsce międzywojennej (Warsaw, 2006), discusses at length the identity discourse among the Polish Jewry of the interwar period. 
ethnic structure' of Poland in the two interwar decades is constructed. As part of these procedures, borderlines are set, for that matter, to separate the Belarusian and Ukrainian 'ethnic territories', which in turn leads to the conclusion whereby the Poleshuks - the people of Polesia - from the Kobryń county were, 'objectively', Ukrainians, and those from Sarny county were 'essentially' Belarusian. Another, pretty peculiar, practice consists in using the stereotypical clusters, coined in the nineteenth century, such as 'Pole-Catholic' or 'Ukrainian-Greek Catholic', as they apparently more precisely describe the self-identity of individuals in the twentieth century than what these individuals might have themselves declared. ${ }^{14}$ Where the personal testimonies concerning self-identification of millions of individuals from the entire interwar period are found incompliant with a model such as 'Pole-Catholic', it is maintained that such individuals uttered some unconscious statements or were forced to make a false testimony by a 'daemonic Polish state'. ${ }^{15}$

Where are the reasons for which the archaic vision of nation, and struggle of nations as the axis of the history of Poland, has for so long been shared by a considerable number of historiographers? As it seems, there are three essential reasons. The first is a peculiar source trap. In analysing Polish-Ukrainian or Polish-Jewish relations, historians make use of political commentaries, documentation of the activities of political parties or factions, administrative and police files, policy proposals, reminiscences of activists, artistic works with a national message, and the like. When researching the state's attitude toward citizens of various nationalities, historians tend to use documents that directly relate to 'minority questions'. This being the case, the otherwise extremely important rules of loyalty toward the historical source and respect for the ideas and views of participants of the reality under research appear to be an intellectual trap. Reporting

${ }^{14}$ Zbigniew Landau and Jerzy Tomaszewski, Robotnicy przemystowi w Polsce. Materialne warunki bytu 1918-1939 (Gospodarka Polski 1918-1939, Warsaw, 1971), 88-97; Grzegorz Hryciuk, Przemiany narodowościowe i ludnościowe w Galicji Wschodniej i na Wotyniu w latach 1931-1948 (Toruń, 2005).

${ }^{15}$ For a dispute with this approach, see Włodzimierz Mędrzecki, 'Liczebność i rozmieszczenie grup narodowościowych w II Rzeczypospolitej w świetle wyników II spisu powszechnego (1931 r.)', Dzieje Najnowsze, xv, 1-2 (1983), 231-52; for a polemics by Jerzy Tomaszewski, see idem, 'W sprawie artykułu Włodzimierza Mędrzeckiego', Dzieje Najnowsze, xvi, 2 (1984), pp. 191-2. 
on the sources, the historian authorises the reality as viewed by the participants of the events of the time who were immediately involved in the national activity and ethnic conflicts.

The other reason is a political context of the historical research in the field of ethnic relations in the interwar period. From the standpoint of the Soviet (and not only Soviet) propaganda and, subsequently, historiography, the interpretation of the reality of the Second Republic contained in the narratives of the exponents of the period's Ukrainian, Belarusian, or Jewish national movement was an excellent tool used to discredit interwar Poland and, simultaneously, offered justification for the USSR's policy toward Poland before and after September 17, 1939. A number of representatives of the national Ukrainian, Belarusian, or Lithuanian historiography, as well as some Jewish historians, evoke, not less willingly than the Soviet historians do, such sources as unbiased and unimpeachable pieces of evidence showing the immensity of guilt encumbering the opposite (that is, Polish) side of the conflict. ${ }^{16}$ The situation is more complex in Polish historiography, though. Some of its representatives have been paying back the debaters with the same currency, responding to the charges of Polonisation with quotations from sources identifying the activity of national minorities with anti-state activity and terrorism. ${ }^{17}$ Some are of the opinion that Poles ought to humbly accept the rebukes, analyse them, and make use of the situation to draw useable conclusions from the past for the future. ${ }^{18}$

The third reason is an archaic, but dominant among today's historians, understanding of identity as a stable complex of convictions and attitudes that are 'objectively' interrelated with the individual's membership in a defined social group, coupled with the conviction that ethnic identification is superior to all the other constituents of identity. In consequence, historians tacitly assume that the way of comprehending the social reality as displayed by the national elite is reproduced by all the other, 'nationally-conscious', members of the community. The result is that historical narrative becomes imbued

${ }^{16}$ Bohdan Hud, Ukraincy i Polacy na Naddnieprzu, Wotyniu $i$ w Galicji Wschodniej $w$ XIX i pierwszej połowie XX wieku. Zarys historii konfliktów społeczno-etnicznych, trans. Anna Korzeniowska-Bihun and Mariya Hud (Warsaw and Lviv, 2013).

${ }^{17}$ Lucyna Kulińska, Działalność terrorystyczna $i$ sabotażowa nacjonalistycznych organizacji ukrainskich $w$ Polsce w latach 1922-1939 (Cracow, 2009).

18 Jerzy Tomaszewski, Rzeczpospolita wielu narodów (Warsaw, 1985). 
with phrases such as "Ukrainians in the Second Republic denied the legitimacy of the State authorities", or, "Poles challenged the Ukrainians' loyalty toward the Polish State", which refer to national communities as unanimous monolithic groups. In this context, it is worth drawing attention to the very reserved position of the historians researching into the Second Republic period with respect to the category of 'broad transitional borderland', which over the last decades has been growing increasingly popular in sociology and cultural anthropology - and which on the Polish historiographical soil had once been propagated, without much success, by Józef Chlebowczyk. ${ }^{19}$

In the opinion of the conference organisers, the 'nation-centric' paradigm in the description of the Second Republic's social reality has exhausted its cognitive potential. As part of it, the course of the spectacular conflicts on grounds of nationality has been registered, hypotheses concerning their origins formulated, and those guilty of adverse phenomena, pathologies, and failures identified. It is obviously possible to follow up this approach: there will always be a wealth of increasingly detailed matters to be examined; in particular, the mutual accusations regarding the extent of guilt of the individual dramatis personae will never come to an end. However, this approach offers no possibility to deepen the understanding of the essence of the social and political life or culture of the Second Republic.

The inspirations that have incited the participants of the research project focused on the society of the Second Republic to try and verify the above-described 'nation-centric' look at the nationality and ethnicity questions are various. The conviction ought to be mentioned in the first place whereby historians should take account in their research of the findings of social sciences which in the last decades have called into question the perception of identity of individuals and collectivities as a stable, codifiable, and hierarchisable set of views and attitudes. In the contemporary social sciences, the assumption whereby identity should be approached not in terms of a determined status but, instead, as a process of the individual's and group's incessant

${ }^{19}$ Józef Chlebowczyk, Procesy narodotwórcze we wschodniej Europie środkowej $w$ dobie kapitalizmu: od schytku XVIII do poczattków XX w. (Warsaw and Cracow, 1975), see also the article by Chlebowczyk, 'Some Issues of National Assimilation and Linguistic-Ethnic Borderland (In the Area of Former Austro-Hungarian Monarchy)', Acta Poloniae Historica, cviii (2013), 149-95 (the Archive section). 
dialogue with the surrounding world, is not open to doubt. It is assumed as an obvious thing that in various social situations and contexts of life, identity tends to be organised through a variety of dominants. It can be national awareness, in some cases; otherwise, gender self-identification, generational belonging, or sense of membership in a local community. ${ }^{20}$

That the Second Republic society experienced extremely complex and unambiguous processes of constructing individual and collective identity, in the context of nationality issues, was testified already by the research conducted in the two interwar decades. The studies on the shaping of social identity, carried out by Józef Chałasiński in Silesia and Józef Obrębski in Polesia, ${ }^{21}$ can be mentioned in this context. A similar track was pursued by Stanisław Ossowski, in the post-war years. ${ }^{22}$ These scholars have demonstrated that in the complex processes of supra-local integration taking place in the Polish lands in the nineteenth and twentieth century, national identification did not have to be a prevailing element; it was, moreover, often perceived as coercion superimposed from the outside (by the state or by various 'agitators'). In search of historical verification of the sociological analyses, Olga Linkiewicz analyses - in what is her doctoral thesis - the character of the relationships between the various ethnic, cultural, and denominational groups within the local communities, and the relations between local peasant communities and governmental institutions and nationalist movements, in selected regions of East Galicia between the World Wars. She has found that for the peasant inhabitants of the ethnic borderland, the modern nation-state categories of social identification remained alien. They tried to defend the cohesiveness of their local milieus where 'being local' remained the basic self-identification criterion. ${ }^{23}$

${ }^{20}$ Aldona Jawłowska (ed.), Wokót problemów tożsamości (Warsaw, 2001); Zbigniew Bokszański, Tożsamości zbiorowe (Warsaw, 2005).

${ }^{21}$ Józef Chałasiński, Antagonizm polsko-niemiecki w osadzie fabrycznej 'Kopalnia' na Górnym Ślasku. Studium socjologiczne (Warsaw, 1935); Józef Obrębski, Studia etnosocjologiczne, i: Polesie, ed. and foreword Anna Engelking (Warsaw, 2007).

${ }^{22}$ See the article by Ossowski in this issue of Acta Poloniae Historica, the Archive section.

${ }^{23}$ Olga Linkiewicz, 'Wiejskie społeczności lokalne na obszarze polsko-ukraińskiego pogranicza etnicznego w Galicji Wschodniej 1918-1939', typescript kept at the Institute of History, Polish Academy of Sciences, Warsaw (2009). 
Anna Landau-Czajka's research on the identity of Jews and people of Jewish descent in the interwar period has posed a serious challenge to the perception of the nationality issues dominating in the Second Republic research. As this author argues, one's ethnic or national self-identification often did not correspond with his or her cultural self-identification. No less important is her ascertainment indicating the complexity of the relation between ethnic/national self-identification and the political attitudes of Jews and people of Jewish background in interwar Poland. ${ }^{24}$

The session whose materials are partly presented here has produced an outcome that appears ambiguous, in the context of the questions posed by the organisers. A total of twenty papers were delivered at the session. Jewish community was one of the main characters in nine of them. Discussed, or at least indicated, was the Jews' attitude to the emerging Polish state, and the legal status of the Jewry in the early interwar years (Marcos Silber, Aleksandra Imiłowska); the Jews' attitudes towards Poland and things Polish, in the context of Jewish identity discourse, in 1918-39 (Shoshana Ronen, Ireneusz Piekarski, Alina Molisak); the Zionist movement (Rona Yona); the living conditions of the Jews, and relations between this ethnic group and representatives of other nationalities within the Second Republic society (Anna Novikov, Natalia Aleksiun). The materials presented and the discussion that unfolded at the session have confirmed that there is a general prevalent agreement in today's Polish and Jewish historiography as regards the overall profile of the Jewish community and its situation in the interwar Poland. The differences in the assessment of questions such as the Polish state's attitude toward the Jews as a national group and religious community, the nature and mechanisms of the social and civilisational modernisation processes, or the course and consequences of nation-forming processes in the Second Republic, appearing in the course of the discussion, may be deemed natural.

Some of the papers dealing with the Jewish issues, and most of the other papers, were detailed studies reflecting certain general problems. This is particularly true for the presentations by Torsten Lorenz, Piotr Cichoracki, Anna Novikov, Ireneusz Piekarski, as well as for the series of texts on the peasantry-related topics - i.e. those

${ }^{24}$ Landau-Czajka, Syn będzie Lech... 
by Kai Struve, Anna Engelking, Aleksander Smalańczuk, and Olga Linkiewicz. ${ }^{25}$ It seems that the authors of these particular papers, albeit belonging to various scholarly milieus and representing various sub-disciplines of historical sciences, have assumed a shared cognitive perspective in their research. Their point of departure was the question about ethnic/national self-identification within the global social identity. For instance, the research into the local community of a small town in Wielkopolska region was not aimed at confirming a pre-assumed character of the relations between the Polish and the German communities within the said locality. Instead, producing a material was expected that would be used in answering the question, what those relations were actually like (T. Lorenz). Hence, a moderately optimistic statement could be formulated whereby, although the paradigm in the research of the Second Republic's nationality issues has not been altered, the current of reflection exceeding the limits of a 'nation-centric' point of view is not only clear but it also brings some interesting results. Some of them are presented in this volume, thanks to the receptive attitude of the Editorial Team of Acta Poloniae Historica.

trans. Tristan Korecki

${ }^{25}$ See the articles by T. Lorenz, P. Cichoracki, A. Novikov, K. Struve, A. Engelking, and O. Linkiewicz in this issue of Acta Poloniae Historica. 